Pesq. Vet. Bras. 36(10):986-992, outubro 2016

DOI: $10.1590 / S 0100-736 X 2016001000011$

\title{
Bacterial cellulose and bacterial cellulose/polycaprolactone composite as tissue substitutes in rabbits' cornea $^{1}$
}

\author{
Rodrigo V. Sepúlveda², Fabrício L. Valente², Emily C.C. Reis ${ }^{2}$, Fabiana R. Araújo², \\ Renato B. Eleotério ${ }^{2}$, Paulo V.S. Queiroz ${ }^{2}$ and Andréa P.B. Borges ${ }^{2 *}$
}

\begin{abstract}
Sepúlveda R.V., Valente F.L., Reis E.C.C., Araújo F.R., Eleotério R.B., Queiroz P.V.S. \& Borges A.P.B. 2016. Bacterial cellulose and bacterial cellulose/polycaprolactone composite as tissue substitutes in rabbits' cornea. Pesquisa Veterinária Brasileira 36(10):986-992. Programa de Pós-Graduação em Medicina Veterinária, Departamento de Veterinária, Universidade Federal de Viçosa, Avenida Peter Henry Rolfs s/n, Viçosa, MG 36570-900, Brazil. E-mail: andrea@ufv.br

In order to test the performance of bacterial cellulose/polycaprolactone composite (BC/ PCL) and pure bacterial cellulose (BC) as tissue substitutes in rabbits' cornea, a superficial ulcer containing $5 \mathrm{~mm}$ in diameter and $0.2 \mathrm{~mm}$ deep was made in the right cornea of 36 rabbits, then a interlayer pocket was created from the basis of this ulcer. Twelve rabbits received BC/PCL membrane and 12 were treated with BC membranes, both membranes with $8 \mathrm{~mm}$ in diameter. The remaining rabbits received no membrane constituting the control group. The animals were clinically followed up for 45 days. Three animals of each group were euthanized at three, seven, 21, and 45 days after implantation for histological examination of the cornea along with the implant. Clinical observation revealed signs of moderate inflammatory process, decreasing from day $20^{\text {th }}$ in the implanted groups. Histology showed absence of epithelium on the membranes, fibroplasia close to the implants, lymph inflammatory infiltrate with giant cells, collagen disorganization, with a predominance of immature collagen fibers in both groups with implants. Although inflammatory response is acceptable, the membranes used does not satisfactorily played the role of tissue substitute for the cornea during the study period.
\end{abstract}

INDEX TERMS: Bacterial cellulose, bacterial cellulose/polycaprolactone composite, tissue substitutes, rabbits, cornea, corneal ulcer, biomaterial, tissue engineering, animal model, Gluconacetobacter xylinu.

RESUMO.- [Celulose bacteriana e composto de celulose bacteriana/policaprolactone para substituto tissular na córnea de coelho.] Com objetivo de testar o desempenho do compósito celulose bacteriana/policaprolactona (CB/PCL) e da celulose bacteriana pura (CB) como substitutos teciduais em córnea de coelhos, foi realizada uma úlcera superficial de $5 \mathrm{~mm}$ de diâmetro e $0,2 \mathrm{~mm}$ de profundidade na córnea direita de 36 coelhos, criando-se um bolso interlamelar a partir da base dessa úlcera. Doze animais receberam a membrana do compósito CB/PCL e 12

\footnotetext{
${ }^{1}$ Received on January 24, 2016.

Accepted for publication on May 23, 2016.

${ }_{2}$ Programa de Pós-Graduação em Medicina Veterinária, Departamento de Veterinária, Universidade Federal de Viçosa (UFV), Avenida Peter Henry Rolfs s/n, Viçosa, MG 36570-900, Brazil. *Corresponding author: andrea@ufv.br
}

foram tratados com membranas de $\mathrm{CB}$, ambas com $8 \mathrm{~mm}$ de diâmetro, os coelhos restantes não receberam nenhuma membrana, constituindo o grupo controle. Os animais foram acompanhados clinicamente até 45 dias. Três animais de cada grupo sofreram eutanásia aos três, sete, 21 e 45 dias após o implante das membranas para análise histológica da córnea juntamente com o implante. À observação clínica, houve sinais de processo inflamatório moderado, diminuindo a partir do $20^{\circ}$ dia nos grupos implantados. A histologia demonstrou ausência de epitélio sobre as membranas, fibroplasia próxima aos implantes, infiltrado inflamatório linfo-histiocitário com células gigantes, desorganização do colágeno, com predominância de fibras imaturas de colágeno em ambos os grupos com implantes. Embora a resposta inflamatória seja aceitável, as membranas utilizadas não desempenharam satisfatoriamente o papel de substituto tecidual para a córnea, no período estudado. 
TERMOS DE INDEXAÇÃO: Celulose bacteriana, celulose bacteriana/policaprolactone, substituto tissular, córnea, coelho, úlcera de córnea, biomaterial, engenharia de tecidos, modelo animal, Gluconacetobacter xylinus.

\section{INTRODUCTION}

Corneal opacities culminating in blindness or visual impairment occurs in nearly 10 million cases worldwide (Mariotti \& Pascolini 2012, Stevens et al. 2013). Progressive ulcers or deep corneal injuries require lamellar or emergency keratoplasty to restore eye integrity and prevent complications such as angle adhesions, opacity, glaucoma and endophthalmitis (Lai \& Hsiue 2007). The most commonly used treatment for this cases is corneal grafts, however, after 4 to 5 years post-treatment, the rejection rate increases from $10 \%$ to $25 \%$ and continues to increase throughout the patient's life (Nishida et al. 2004), despite being the cornea and the anterior chamber immunologically privileged sites. In fact, they produce tolerant and downregulation immune responses, allowing application of keratoplasty techniques to recover the integrity and refractive state of the cornea without concomitant immunosuppression theraphy (Biros 2008), and penetrating xenografts with immunosuppression only in initial days (Townsend et al. 2008). Besides these facts, according to Pressler (2010), corneal allografts have still shown the best results in keratoplasty, however, they have limited supply and may not be readily available. Thus, biopolymers are becoming more studied in replacement of corneal tissue to retrieve the appropriate refractive status of the eye (Espana et al. 2011). To be applied to the cornea, a material must be transparent, allowing epithelial growth on its surface, should not trigger an exaggerated immune response and should allow fibroplasia and deposition of extracellular matrix in the interface (Tanure 2006). Bacterial cellulose (BC) is a polymeric membrane produced by the bacterium Gluconacetobacter xylinus, presents biocompatibility (Helenius et al. 2006), besides being semi-transparent, hydrophilic, flexible and semipermeable, characteristics that allow its application in tissue engineering (Klemm et al. 2001). The BC is biocompatible (Chen et al. 2009) and not degradable in animal tissues (Yadav et al. 2010), which can make it a useful polymer basis for integrating devices for corneal applications. However, BC is inelastic and its transparency is limited. Therefore, seeking to enhance the optical and mechanical characteristics of $\mathrm{BC}$, in order to make it suitable for implantation in the cornea, it has been proposed the addition of polycaprolactone (PCL) to $\mathrm{BC}$ membranes. The PCL is a thermoplastic, biodegradable and biocompatible polymer (Pok et al. 2010), also having viscoelasticity (Duling et al. 2008). The bacterial cellulose/ polycaprolactone (BC /PCL) composite formed more malleable membranes with high transparency (transmittance 85\%) when compared with pure BC membranes (Barud et al. 2013) and its biocompatibility has been shown (Grobelski et al. 2014). Thus, the objective of this study was to evaluate in vivo the ability of two membranes, BC/PCL and BC, in regenerating superficial corneal ulcers in rabbits with the hypothesis that these membranes are biocompatible and integrated into the cornea, favoring epithelialisation, and therefore the regeneration of experimental ulcers.

\section{MATERIALS AND METHODS}

The procedures adopted in this study were approved by the Ethics Committee on the use of animals of the institution (Protocol $\mathrm{n}^{\text {o }}$ 88/2011).

The membranes were prepared using bacterial cellulose (BC) and polycaprolactone associated with bacterial cellulose (BC/ PCL), as described by Barud et al. (2013). They were cut into a circular shape having $8 \mathrm{~mm}$ diameter and sterilized by gamma radiation $(20 \mathrm{KGV})$.

Thirty-six females, healthy, with an average weight of $3.2 \mathrm{~kg}$ and an average age of 4 months New Zealand rabbits underwent surgical procedure for induction of corneal ulcer in the right eye. Previously to the experimental surgical procedure, we evaluated the eye (with clinical analysis describe above, including basal v) in order to discard any lesions or disorders that could compromise the trial. For inducing the experimental ulcer, the animals were anesthetized (ketamine and xylazine, $30 \mathrm{mg} / \mathrm{kg}$ and $5 \mathrm{mg} / \mathrm{kg}$, respectively, intramuscularly; maintenance with isoflurane diluted in oxygen) and surgical field was prepared as routine for ophthalmic surgery. For better intraoperative analgesia, eye drops of $4 \%$ lodocaine was instilled in the operated eye every 10 minutes until the end of the procedure. Figure 1 shows the surgical procedure used in this study. Briefly a superficial keratectomy was made in the center of the cornea, thus reaching visual axis, in a manner similar to that described by Pontes et al. (2014). However, in this work, the ulcer was made with $5.0 \mathrm{~mm}$ in diameter and 0.2 mm thick using a disposable biopsy punch (Kolpast, Brazil) and an interlayer pocket, from the base of the ulcer was made with a delamination spatula that advanced about $3.0 \mathrm{~mm}$ toward the limbus. This pocket was created for insertion and positioning of the membranes in the animals that received the membranes. Twelve animals were selected to receive treatment with BC/PCL membrane and twelve received $\mathrm{BC}$ membrane. The remaining animals have not received the membranes, constituting the control group.

For post-operative analgesia, morphine was administered (1 $\mathrm{mg} / \mathrm{kg}$, subcutaneously, every 12 hours for two days). In the first seven days, the eyes were cleaned with sterile $0.9 \%$ saline solution with the aid of a eye dropper. Antimicrobial therapy was made with application of eye drops based on $0.175 \%$ neomycin, 10,000 IU polymyxin B and 400 IU bacitracin, one drop every four hours during the daytime. For cycloplegia, $0.5 \%$ atropine eye drop base was applied twice a day for two days.

Clinical examination was performed every 24 hours in the first two weeks and every 48 hours in the following weeks until the 45th day, always by the same examiner and in the morning. This examination included the Schirmer tear test I, the presence or absence of blepharospasm, eye discharge and conjunctival hyperemia, the last three with the assistance of direct light. With the aid of slit lamp microscope and a magnification of ten times, edema and iris hyperemia were assessed. The same equipment was used to assess vascularity according to the following scores: 0 to absence of vessels, one for up to four vessels without progression toward the lesion focus, 2 for five to eight vessels progressing toward the lesion focus, and 3 for more than eight vessels progressing to the focus of injury. In addition, the fluorescein test was performed to evaluate the presence or absence of the epithelialization in the operated area.

Three animals from each group (BC/PCL, BC and control) were euthanized by thiopental over-dose at three, seven, 21 and 45 days after implantation. The operated eyes were collected and fixed in Bouin solution for 24 hours, and then the samples were 
transferred to $70 \%$ alcohol. Thereafter, the fragments were processed routinely for histology with paraffin embedding and. $4 \mu \mathrm{m}$ thick cuts were made. The cuts were stained with hematoxylin and eosin (HE) and picro-sirius. In the first staining, we evaluated (Olympus BX-53, Japan) the following parameters: epithelialization the injured area (we attributed the score 0 when absent, 1 when incomplete and 2 when complete), inflammatory infiltrate and edema ( 0 when absent, 1 when mild, 2 when moderate and 3 when intense), fibroplasia of the injured area (present or absent) and characterization of cell types involved in the repair process. On picrosirius red staining, collagen was evaluated following the recommendations of Rich \& Whittaker (2005) and Lattouf et al. (2014) and observed under polarized polychromatic light (Olympus BX-53, Japan)

To evaluate variation of clinical signs of the animals over time and treatments, mixed-effect generalized linear models were constructed with binomial distribution errors. Simplification of the models were made withdrawing no significant interactions. Significance was checked by comparing the two models using ANOVA and obtaining the minimum suitable model. Thereafter, contrast analysis to categorical variable (treatment) at all levels was performed to determine what was possible to amalgamate. The variables obtained from histological analysis were submitted to Kruskal-Wallis test followed by the Student-Newman-Keuls, in case of significance. For all analyzes was considered $\alpha=0.05$. The expression of collagen was presented descriptively.

\section{RESULTS AND DISCUSSION}

In all groups, Schirmer tear test's value increased from the first day and remained high for eight days (when compared to previously collected baseline values before experimental surgery) and then declined until normal levels, around the $15^{\text {th }}$, with no statistical difference between groups $(p=0.362)$. It is natural that tear production increases in the first days after injury to corneal surface, as tear serves as the first line of ocular surface's defense, carrying inflammatory cells, antibodies and antibacterial substances to the affected area. The subsequent normalization of tear secretion in all groups demonstrated that implants did not affect the production of the tear over time. The vascularization was more intense in the treated groups $(\mathrm{p}<0.001)$ compared to the control, however, it did not differ when the two groups were compared over time $(p=0.073)$, with vessels coming from the entire limbal circumference almost invariably reaching the area of the implants. In these groups, intensity of the vasculature varied between 2 and 3 until the end of evaluation period, while the control group did not exceed grade 1 , returning to 0 from $33^{\text {rd }}$ day. According to Ellenberg et al. (2010), corneal vascularization is expected whenever lesion reaches stroma or deeper layers of the cornea; this is an important way of carrying cells and inflammatory mediators required for the repair process. As in this work, Macedo et al. (2010) observed highest degree of vascularization between 15 and 48 days when applying bacterial cellulose (BC) to cover ulcers in rabbits' corneas. This demonstrates that the same BC stimulated corneal vascularization when used on cornea's surface.

Blepharospasm, ocular discharge and conjunctival hyperemia significantly increased over time in BC/PCL and $\mathrm{BC}$ groups compared to control $(\mathrm{p}<0.001, \mathrm{p}<0.001$ and $\mathrm{p}=0.038$, respectively), but there was no statistical difference between the $\mathrm{BC} / \mathrm{PCL}$ and $\mathrm{BC}$ groups to these signals $(p=0.336, p=0.629$ and $p=0.079$, respectively). Blepharospasm was present in most eyes in BC/PCL (75\% of twelve eyes) and $\mathrm{BC}$ (58.3\% of twelve eyes) groups between 15 and 20 days, being resolved until 33 day, while in the

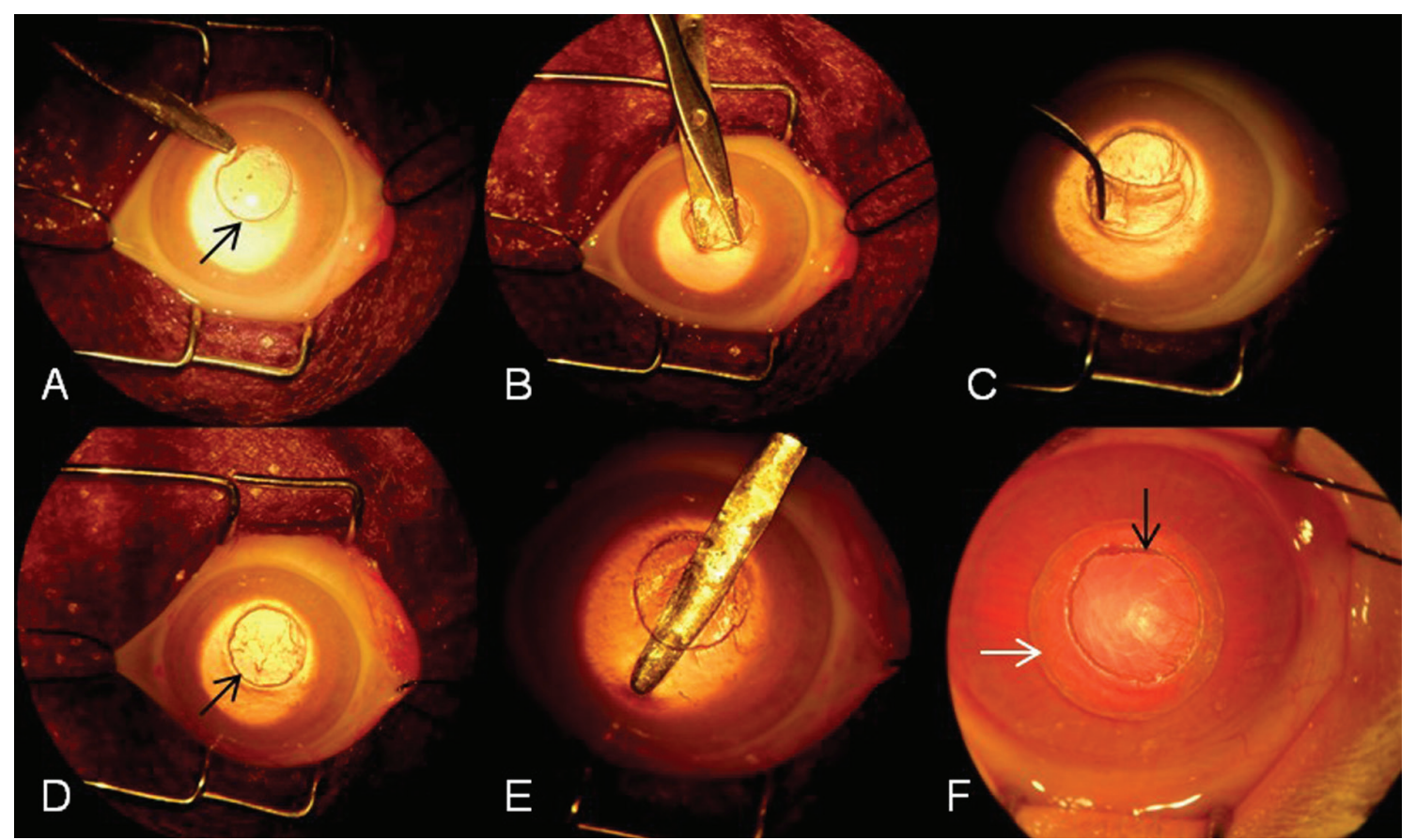

Fig.1. Surgical technique for BC/PCL and BC implantation. (A) Edge of the corneal trepanation (arrow). (B,C) Lamellar dissection. (D) Edge of complete superficial lamellar keratectomy (arrow). (E) Intrastromal insertion of spatula to produce a pocket. (F) Insertion of the membrane into the interlayer pocket; edge of corneal trepanation (black arrow); edge of the membrane inside the interlayer pocket (white arrow). 12x. 
control group (33.3\% of twelve eyes), it disappeared until the fifth day. This sign expresses painful sensation, being observed in many animals in later periods, suggesting that implants urged a more lasting inflammatory response (Wilson et al. 2001).

Eye discharge was present in most animals for two days in all groups (50\% in BC/PCL and control groups and $58.3 \%$ in BC group), while conjunctival hyperemia was present until sixth day in the control group, lasting up to 21 days in BC/PCL and BC groups, reinforcing the fact that implants stimulated a longer initial inflammatory response.

Corneal edema was present from day one in control group while in the groups that received the implant, cornea started to get opaque after the third day. This result shows that the membranes protected ocular surface in the absence of the epithelium, not allowing the fluid intake, which immediately causes edema, being observed only late opacity which, according to Qazi et al. (2010), may result from infiltration and cellular changes that occur during corneal wound healing, and not the stromal water change. There was no significant difference in this variable between groups $(\mathrm{p}=1.000)$.

Iris hyperemia was no longer observed from the fourth day in the control group, suggesting that this clinical sign is related only to the surgical procedure in that group. In BC/ PCL and BC groups, iris hyperemia increased significantly over time as compared to control $(\mathrm{p}<0.01)$. This fact corroborates the observation of a more significant inflammatory response caused by implants, including internal structures. There was no significant difference in this variable between the groups BC/PCL and BC $(p=0.278)$. Wu et al. (1998) suggest that corneal implants always promote some type of inflammatory reaction, this should not be overstated, culminating in the expulsion of the biomaterial, or promoting overgrowth of epithelium and scar tissue. There was no complete implant extrusion in our study.

Fluorescein staining was positive until the fourth day in control group, significantly decreasing over time in relation to BC/PCL and BC groups $(\mathrm{p}<0.001)$. This signal is indicative that there was no complete epithelialization on the implants. This could be due to corneal epithelium characteristics that have, on its surface, squamous cells strongly attached so as not to leave gaps, providing a flat and homogeneous surface, which together with the tear film do not allow the accumulation of debris and microorganisms (Qazi et al. 2010).

Statistical analysis of histologic parameters showed difference between the groups ( $\mathrm{p}<0.05$, Kruskal-Wallis test), but post-hoc test was unable to validate this difference. The analysis of samples taken at three days revealed neutrophilic infiltrate adjacent to the injured area and early epithelial proliferation from the edge of the lesion in the all three groups, but not in the intrastromal region (Fig.2A,B). At seven days, there was moderate neutrophilic inflammatory infiltrate in all groups (Fig.2C). At this point, fibroblast proliferation was noted even nearby the implants. The epithelialization was complete in control group; however, in $\mathrm{BC} / \mathrm{PCL}$ and BC groups, epithelialization has not improved, remaining the same as in previous period. In the control group, these observations are consistent with normal corneal regeneration (Qazi et al. 2010). Failure advance of epithelialization in animals with implants provides evidence that the surface of the membranes did not favor adhesion and growth of the epithelium. At 21 days, the inflammatory infiltrate was no longer observed in the control group animals, while in BC/PCL and BC groups was observed a lymphohistiocytic infiltrate, mild to moderate vessels in the injured area, fibroblasts adhered to the membrane and discreet presence of giant cells (Fig.2D). This infiltration is indicative of chronic inflammatory process because, as described by Kumar et al. (2008), these cells act in a bidirectional manner causing a continuous cycle of cell activation, which replenishes the population of inflammatory cells in situ for extended periods. A similar situation to the one presented on 21 day was present at 45 day in BC/PCL and $\mathrm{BC}$ groups, with the persistence of lymphohistiocytic infiltrate in discreet to moderate (Fig.2E,F). Giant cells were found in mild to moderate intensity, being located mainly in the margins of the implants (Fig.2G), reinforcing the hypothesis that implants stimulate a chronic corneal response, with foreign body response. Trinkaus-Randall et al. (1991) and Wu et al. (1998) demonstrated the biocompatibility of different materials in the cornea, reporting the presence of inflammatory cells within 12 weeks, but involving no giant cells. The inflammatory process observed in histology suggests that BC/PCL and BC membranes did not show the same biocompatible behavior like that shown by Helenius et al. (2006) with humid bacterial cellulose membranes in rat's subcutaneous tissue, which showed good integration with tissue and no significant inflammation. Data like this should be compared with caution, since implants were placed in different species and tissues, which can generate different responses. In addition, for this study, BC membranes were dried before being prepared for implantation. Other researches has shown excellent biocompatibility of humid BC, such as the ones used by Klemm et al. (2001) and Wippermann et al. (2009) who applied humid BC tubes as a substitute for in vivo vascular segments and did not observed severe inflammation or signs of rejection.

Also at 45 days, in addition to giant cells, were observed fibroblasts attached to the membranes (Fig. 2G); however, the absence of pores (Barud et al. 2013) limited cell migration, and therefore, no fibroplasia inside implants, which could suggest the prolonged stay of these implants in corneal tissue. In this period, we also observed inflammatory edema between the stroma and the biomaterial (Fig.2E), mainly in animals with higher inflammation degree.

Epithelialization was not completed in BC/PCL and BC groups at 45 days, whereas in control group had normal epithelium (Fig.2H). This fact could also be explained by the low degree of hydration and lack of pores that implants present. Studies show the importance of good hydration of the surface of biomaterials and the presence of pores for passage of growth factors, conditions that facilitate the growth of not only epithelium, but also its survival (Ma et al. 2011).

In samples stained with Sirius red was not observed any change in collagen structure at three and seven days (Fig.3A and $3 \mathrm{D}$ ), when greater amount of mature collagen in rela- 


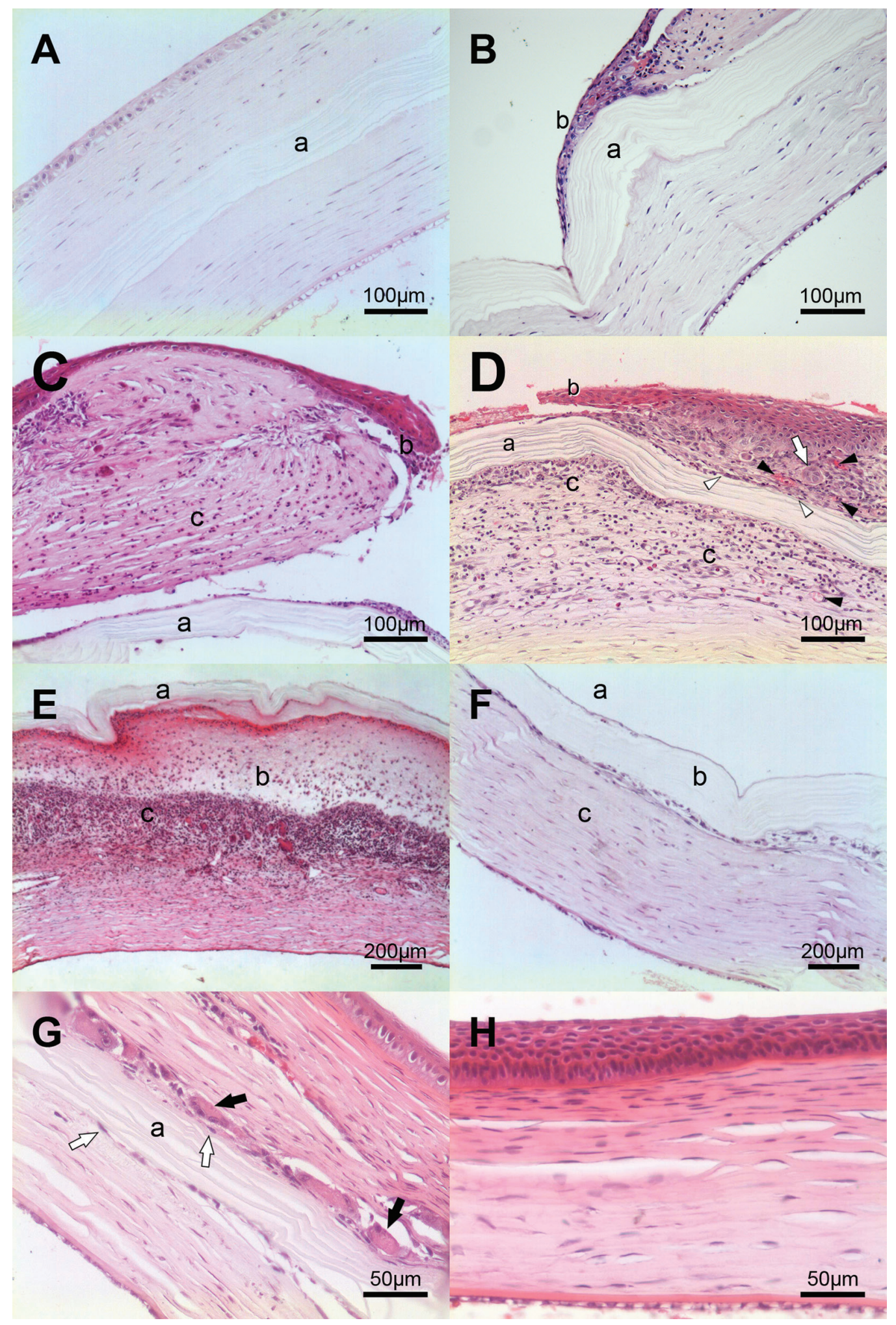

Fig.2. Corneal ulcer region. (A,B) Respectively, intrastromal and peripheral regions of implant $(\mathrm{a}=\mathrm{implant;} \mathrm{b}=\mathrm{epithelialization})$. $(\mathbf{C})$ Edge of the corneal ulcer with BC membrane into intrastromal space seven days after implantation $(a=$ implant; $b=$ epithelialization; $\mathrm{c}=$ stroma with neutrophilic infiltration). (D) Edge of the corneal ulcer with BC/PCL membrane into intrastromal space 21 days after implantation (a: implant; b: epithelialization; c: stroma with lymphohistiocytic infiltration; white arrow: giant cell; white arrow head: fibroblasts; black arrow head: blood vessels). (E,F) Central area of corneal ulcer 45 days after BC/PCL membrane implantation, with no epithelialization along the biomaterial and presence of mild inflammatory infiltration $(a=i m p l a n t ; b=e d e m a ; c=s t r o m a$ with lymphohistiocytic infiltration). (G) Intrastromal space 45 days after surgery in BC group (a = implant; black arrow =: giant cell; white arrow = fibroblast). (H) Edge of corneal ulcer in the control group with complete epithelialization. HE, obj.10x (A-D), obj.20x (E,F), obj.40x $(\mathrm{G}, \mathrm{H})$. 


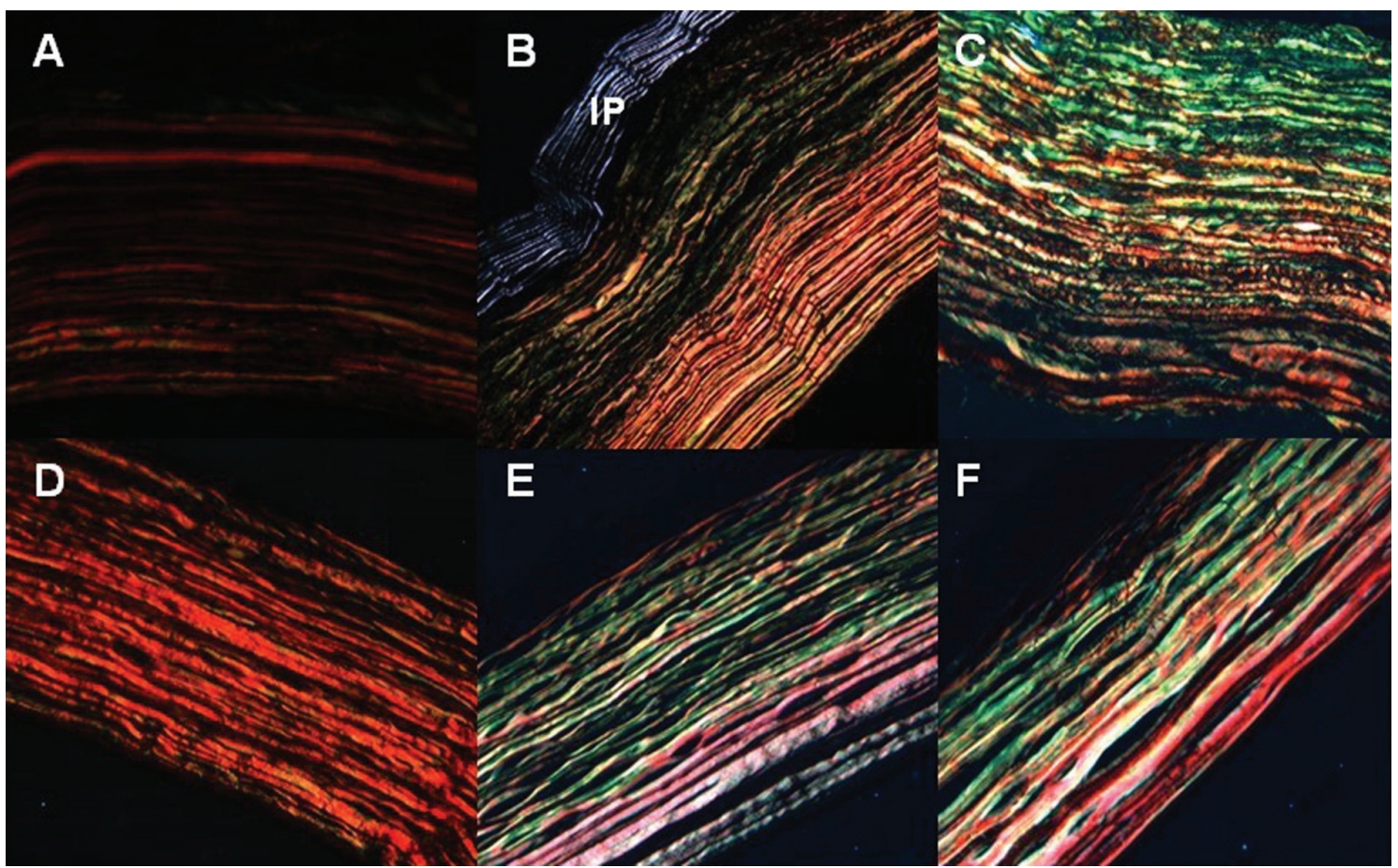

Fig.3. Corneal ulcer region. Sirius red/Polarized light. (A,D) BC/PCL and control groups, respectively, seven days after surgery; mature collagen fibers predominance (red-orange color). (B,E) BC/PCL and control groups, respectively, 21 days after surgery; immature collagen fibers predominance (greenish color). (C,F) BC and control groups, respectively, 45 days after surgery; no predominance of collagen types. IP = implant.

tion to immature collagen fibers were observed. At 21 days, there was a higher proportion of immature collagen fibers and disorganization of collagen fibers in all groups (Figs. 3B and 3E), agreeing with the results of Pontes et al. (2014) that reported prevalence of immature collagen at 21 days after application of amniotic membrane and n-butyl-2-cyanoacrylate to treat penetrating injuries in rabbits' corneas. In the cornea, type I collagen is predominant, since type III is found in small quantities (Qazi et al. 2010). At 45 days, the equivalence between mature and immature collagen and organization of fibers were observed in injured area of control group; however, in implanted animals, were still observed a slight predominance of immature fibers and disorganization of the fibers in focus lesion (Figs. 3C and 3F). This differs from the results of Pontes et al. (2014), who described equivalence between the two types of collagen and organization of fibers at 30 days in all groups evaluated. Thus, it is suggested that the presence of BC/PCL and $\mathrm{BC}$ membranes slowed corneal stroma healing process.

Thus, it can be said that BC/PCL and BC membranes presented initial protective function, while acted as a physical barrier in the absence of the epithelium, and the reaction of the extracellular matrix showed some degree of biocompatibility of the membranes, but limited cellular penetration may have induced a chronic foreign body response, not desirable for the desired function.

\section{CONCLUSIONS}

It can be concluded that BC/PCL and BC implants protected ocular surface and remained stable in corneal tissue during the 45 day follow-up.
There was incomplete epithelialization over the implants, plus a chronic inflammatory condition and disorganization of collagen fibers.

The results demonstrate that these implants are unfavorable to replace the corneal tissue of rabbits.

Acknowledgements.- The authors thank CAPES, CNPq and FAPEMIG for financial support.

Conflict of interest statement.- The authors have no competing interests.

\section{REFERENCES}

Barud H.S., Ribeiro S.J.L., Carone C.L.P., Ligabue R., Einloft S., Queiroz P.V.S., Borges A.P.B. \& Jahno V.D. 2013. Optically transparent membrane based on bacterial cellulose/polycaprolactone. Polímeros 23(1):135-138.

Biros D. 2008. Anterior chamber-associated immune deviation. Vet. Clin. North Am., Small Anim. Pract. 38(2):309-321.

Chen Y.M., Tingfei X., Yudong Z., Tingting G., Jiaquan H., Yizao W. \& Chuan G. 2009. In vitro cytotoxicity of bacterial cellulose scaffolds used for tissue-engineered bone. J. Bioac. Compa. Polym. 24(Suppl.1):137-145.

Duling R.R., Dupaix R.B., Katsube N. \& Lannutti J. 2008. Mechanical characterization of electrospun polycaprolactone (PCL): a potential scaffold for tissue engineering. J. Biomech. Eng. 130(1):011006.

Ellenberg D., Azar D.T., Hallak J.A., Tobaigy F., Han K.Y., Jain S., Zhou Z. \& Chang J.H. 2010. Novel aspects of corneal angiogenic and lymphangiogenic privilege. Progr. Retin. Eye Res. 29(3):208-248.

Espana E.M., Acosta A.C., Stoiber J., Fernandez V., Lamar P.D., Villain F.L., Lacombe E., Alfonso E. \& Parel J.M. 2011. Long-term follow-up of a supradescemetic keratoprosthesis in rabbits: an immunofluorescence study. Graefe's Arch. Clin. Exp. Ophthalmol. 249(2):253-260.

Grobelski B., Wach R.A., Adamus A., Olejnik A.K., Kowalska-Ludwicka K., Kolodziejczyk M., Bielecki S., Rosiak J.M. \& Pasieka Z. 2014. biocompatibility of modified bionanocellulose and porous poly( $\epsilon$-caprolactone) biomaterials. Int. P. Plym. Mater. Polym. Biomater. 63(10):518-526. 
Helenius G., Bäckdahl H., Bodin A., Nannmark U., Gatenholm P. \& Risberg B. 2006. In vivo biocompatibility of bacterial cellulose. J. Biomed. Mater. Res. 76(2):431-438.

Klemm D., Schumann D., Udhardt U. \& Marsch S. 2001. Bacterial synthesized cellulose - artificial blood vessels for microsurgery. Prog. Polym. Sci 26(9):1561-1603.

Kumar V., Abbas K.A., Fausto N. \& Mitchell R.N. 2008. Robbins Patologia Básica. 8ae ed. Elsevier, Rio de Janeiro, p.33-62.

Lai L.J. \& Hsiue G.H. 2007. Functional biomedical polymers for corneal regenerative medicine. React. Funct. Polym. 67(11):1284-1291.

Lattouf R., Younes R., Lutomski D., Naaman N., Godeau G., Senni K. \& Changotade S. 2014. Picrosirius red staining: a useful tool to appraise collagen networks in normal and pathological tissues. J. Histochem. Cytochem. 62(10):751-758.

Ma A., Zhao B., Bentley A.J., Brahma A., Macneil S., Martin F.L., Rimmer S. \& Fullwood N.J. 2011. Corneal epithelialisation on surface-modified hydrogel implants artificial cornea. J. Mater. Sci. Mater. Med. 22(3):663670 .

Macedo L.R., Ribeiro A.P., Conceição L.F., Galera P.D. \& Laus J.L. 2010. Experimental lamellar keratoplasty in rabbits using microfibrilar cellulose membrane. Clinical, morphological and immunohistochemical findings. Ciência Rural 40(2):378-383.

Mariotti S.P. \& Pascolini D. 2012. Global estimates of visual impairment: 2010. Brit. J. Ophthalmol. 96(5):614-618.

Nishida K., Yamato M., Hayashida Y., Watanabe K., Yamamoto K., Adachi E., Nagai S., Kikuchi A., Maeda N., Watanabe H., Okano T. \& Tano Y. 2004. Corneal reconstruction with tissue-engineered cell sheets composed of autologous oral mucosal epithelium. N. Eng. J. Med. 351(12):1187-1196.

Pok S.W., Wallace K.N. \& Madihally S.V. 2010. In vitro characterization of polycaprolactone matrices generated in aqueous media. Acta Biomater. 6(3):1061-1068.

Pontes K.C.S., Borges A.P.B., Eleotério R.B., Frazão A.C.N., Machado D.P.D., Reis E.C.C., Sepúlveda R.V., Duarte T.S. \& Laus J.L. 2014. A new surgical technique to treat corneal perforations using amniotic membrane and surgical adhesive. Arq. Bras. Med. Vet. Zootec. 66(3):655-664.
Pressler B.M. 2010. Transplantation in Small Animals. Vet. Clin. North Am., Small Anim.Pract. 40(3):495-505.

Qazi Y., Wonga G., Monsona B., Stringhamb J. \& Ambatia B.K. 2010. Corneal transparency: Genesis, maintenance and dysfunction. Brain Res. Bull. 81(2):198-210.

Rich L. \& Whittaker P. 2005. Collagen and picrosirius red staining: a polarized light assessment of fibrillar hue and spatial distribution. Braz. J. Morphol. Sci. 22(2):97-104.

Stevens G.A., White R.A., Flaxman S.R, Price H., Jonas J.B., Keefe J., Leasher J., Naidoo K., Pesudovs K., Resnikoff S., Taylor H. \& Bourne R.R. 2013. Global prevalence of vision impairment and blindness: magnitude and temporal trends, 1990-2010. Ophthalmol. 120(12):2277-2384.

Tanure M.A.G. 2006. 0 uso de biomateriais na córnea, p.385-391. In: Oréfice R.L., Pereira M.M. \& Mansur H.S. (Eds), Biomateriais; fundamentos e aplicações. Rio de Janeiro, Cultura Médica.

Townsend W.M., Rankin A.J., Stiles J. \& Krohne S.G. 2008. Heterologous penetrating keratoplasty for treatment of a corneal sequestrum in a cat. Vet. Ophthalmol. 11(14):273-278.

Trinkaus-Randall V., Bonwatt R., Copecchi J., Leibowitz H.M. \& Franzblau C. 1991. In vivo fibroplasia of a porous polymer in the cornea. Invest. Ophthalmol. Vis Sci. 32(13):3245-3251.

Wilson S.E., Mohan R.R., Mohan R.R., Ambrosio Jr R.A., Hong J. \& Lee J. 2001. The corneal wound healing response: cytokine-mediated interaction of the epithelium, stroma, and inflammatory cells. Prog. Retin. Eye. Rese. 20(5):625-637.

Wippermann J., Schumann D., Klemm D., Kosmehl H., Salehi-Gelani S. \& Wahlers T. 2009. Preliminary results of small arterial substitute performed with a new cylindrical biomaterial composed of bacterial cellulose. Eur. J. Vasc. Endovasc. Surg. 37(5):592-596.

Wu X.Y., Tsuk A., Leibowitz H.M. \& Randall V.T. 1998. In vivo comparison of three different porous materials intended for use in a keratoprosthesis. Brit. J. Ophthalmol. 82(5):569-576.

Yadav V., Paniliatis B.J., Shi H., Lee K., Cebe P. \& Kaplan D.L. 2010. Novel in vivo-degradable cellulose-chitin copolymer from metabolically engineered Gluconacetobacter xylinus. Appl. Environ. Microbiol. 76(18):6257-6265. 